\title{
PENGARUH LINGKUNGAN KELUARGA TERHADAP PRESTASI BELAJAR SISWA PADA MATA PELAJARAN EKONOMI PADA SISWA KELAS XI IIS DI SMA BAWARI PONTIANAK
}

\author{
Tri Yatmi Kamariyah, Maria Ulfah, Achmadi \\ Program Studi Pendidikan Ekonomi FKIP Untan Pontianak \\ E-mail: kamariyahtriyatmi@gmail.com
}

\begin{abstract}
This study aims to determine the effect of the family environment on student achievement in economics class XI IIS at SMAS Bawari Pontianak. The method used in this research is descriptive method. the form of the research, the form of research that is determined is the study of relationships (Interrelationship Studies). Data collection techniques are direct communication techniques, indirect communication techniques and documentary study techniques. Data collection tools are questionnaires, interviews and notes. 1) This research is a population of 102 students of class XI IIS SMAS Bawari Pontianak. A sample of 50 students consists of 3 classes. 2) The family environment of class XI IIS SMAS Bawari Pontianak $83.66 \%$ is categorized as very good. Student achievement in class XI ISS SMAS Bawari Pontianak is the highest class XI IIS 1 followed by class XI IIS 2 and the last is class XI IIS 3. 3) There is an influence of family environment on student achievement in class XI ISS SMAS Bawawi Pontianak, the value of $t_{-}$count is obtained $=30.977$ greater than the value of t_table $=2.010 .4)$ How much does the family environment affect student achievement in class XI IIS SMAS Bawari Pontianak, namely Y=31.13+0.530 X
\end{abstract}

\section{Keywords: Family Environment, Learning Achievement}

\section{PENDAHULUAN}

Perkembangan dan kemajuan suatu bangsa ditentukan oleh tinggi rendahnya tingkat ilmu pengetahuan yang ada di dalam suatu negara. Ilmu pengetahuan dan pendidikan merupakan suatu kesatuan yang tidak dapat dipisahkan karena ilmu pengetahuan dapat di peroleh dan di kembangkan di dunia pendidikan.

Pendidikan merupakan suatu proses terhadap anak didik berlangsung terus sampai anak didik mencapai pribadi dewasa susila. Proses ini berlangsung dalam jangka waktu tertentu. Bila anak didik sudah mencapai pribadi dewasa susila, maka ia sepenuhnya mampu bertindak sendiri bagi kesejahteraan hidupnya dan masyarkatnya.

Belajar pada hakikatnya adalah suatu interaksi antara individu dan lingkungan. Lingkungan menyediakan rangsagan terhadap individu dan sebaliknya individu memberikan respon terhadap lingkungan. Lingkungan juga bisa menyebabkan terjadinya perubahan tingkah laku individu, baik yang berupa positif maupun bersifat negatif. Hal ini menunjukan bahwa fungsi lingkungan merupakan faktor yang penting dalam proses belajar.

Penyelenggaraan pendidikan biasanya dilaksanakan melalui dua jalur, yaitu jalur pendidikan formal dan jalur pendidikan non formal. Jalur pendidikan formal merupakan pendidikan yang diselenggarakan di sekolah melalui kegiatan belajar mengajar secara berjenjang dan berkesinambungan. Pendidikan non formal merupakan pendidikan yang diselenggarakan di luar sekolah, melalui kegiatan belajar yang tidak harus berjenjang dan berkesinambungan, seperti kursus komputer, memasak, menjahit dan lain-lain. Berarti bahwa berhasil atau gagalnya pencapaian tujuan pendidikan itu bergantung pada proses belajar yang dialami siswa, baik ketika berada di sekolah maupun di lingkungan rumah atau keluarga.

Lingkungan keluarga yang mendukung proses kegiatan belajar anak akan memberi semangat sehingga dapat berpengaruh secara langsung maupun tidak langsung terhadap 
prestasi belajarnya. Anak akan menerima perhatian lebih dari orang tua dalam proses kegiatan belajarnya akan lebih termotivasi untuk lebih giat dalam meningkatkan prstasi belajarnya. Begitu pula dengan susasan rumah yang tenang dan tentram akan menjadi tempat belajar yang baik bagi anak. Selain itu keadaan ekonomi keluarga yang mendukung dalm memenuhi kebutuhan keluarga serta kebutuhan sekolah akan membuat anak lebih fokus dengan sekolahnya.

Tinggi rendahnya prestasi belajar mencerminkan kualitas pendidikan. Kualitas pendidikan yang bermutu dapat dicapai dengan cara menerapkan proses belajar mengajar yang efektif dan efesien. Prestasi belajar dapat dikelompokkan menjadi prestasi belajar seluruh bidang studi dan prestasi belajar bidang tertentu. Prestasi belajar merupakan bagian akhir dari proses belajar. Banyak siswa yang mengalami masalah dalam belajar, akibatnya prestasi belajar yang dicapai rendah.

Pengertian orang tua dan latar belakang kebudayaan juga sangat berpengaruh terhadap belajar anak. Anak belajar perlu dorongan dan perhatian orang tua. . Bila anak belajar jangan diganggu dengan tugas-tugas di rumah. Tingkat pendidikan atau kebiasaan didalam keluarga juga mempengaruhi sikap anak dalam belajra. Perlu kepada anak ditanamkan kebiasaan-kebiasaan yang baik, agar mendorong semangat anak dalam belajar. Anak lahir dalam lingkungan keluarga dan dalam pemeliharaan orang tua. Orang tua disini memikul tugas sebagai pendidik, pemelihara, pengasuh, pembimbing maupun sebagai guru dan pengasuh bagi anakanaknya serta orang tua merupakan contoh terdekat bagi anaknya Dalam meningkatkan hasil belajar diperlukan kerjasama yang baik antara pihak sekolah dan orang tua siswa. Kenyataan yang ada sekarang ini adalah orang tua cenderung menyerahkan proses pembelajaran siswa sepenuhnya kepada sekolah

Orang tua siswa terlalu sibuk dengan pekerjaannya yang menyebabkan kurangnya perhatian yang mereka berikan dan cenderung acuh terhadap kegiatan belajar anak. Seseorang di didik dan dibimbing dalam keluarga yang kurang kasih sayang dan kurang perhatian, maka siswa tersebut akan tumbuh dan berkembang menjadi anak yang nakal dan pemalas.
Berdasarkan hasil observasi dan wawancara yang dilakukan dengan wali kelas, beliau beranggapan bahwa siswa yang berprestsi dalam pembelajarannya salah satunya dipengaruhi oleh lingkungan keluarga contohnya seperti kurangnya perhatian bertanya orangtua terhadap kegiatan pembelajaran anak setiap harinya.

Pada penelitian ini peneliti mengkhususkan pada kelas XI IIS I SMA Bawari Pontianak. Alasan peneliti memilih kelas XI karena pada saat peneliti melakukan observasi pada kelas XI khususnya kelas XI IIS, kelas tersebut peneliti sudah banyak mengenal siswanya dan sedikit banyak sudah mengetahui lingkungan keluarga mereka dari cerita yang mereka sampaikan kepada peneliti. Peneliti memilih kelas XI IIS dikarenakan pada kelas tersebut banyak siswa yang mendapatkan nilai yang belum mencukupi KKM. Permasalahan tersebut didukung dengan data dokumen hasil belajar siswa kelas XI SMAS Bawari Pontianak.

Berdasarkan hasil rata-rata belajar raport siswa dalam 1 (satu) semester masih banyak dibawah KKM, ketentuan KKM pada sekolah kelas XI di SMAS Bawari Pontianak adalah 75.

Berdasarkan data angket, wawancara, dan dokumentasi prestasi belajar menunjukan sebagian siswa masih banyak tidak memenuhi kriteria ketuntasan minimal. Permasalahan mengenai rendahnya prestasi belajar dikelas XI. Lingkungan keluarga merupakan salah satu komponen penting dalam penelitian prestasi belajar namun guru maupun orang tua siswa belum menyadari hal tersebut.

Berdasarkan uraian diatas maka peneliti tertarik untuk melakukan penelitian dengan judul "Pengaruh Lingkungan Keluarga Terhadap Prestasi Belajar Siswa Pada Mata pelajaran Ekonomi Pada Kelas XII IIS Di SMAS Bawari Pontianak"

Permasalahan umum dalam penelitian adalah "Bagaimana pengaruh lingkungan keluarga terhadap prestasi belajar pada mata pelajaran ekonomi siswa kelas XI IIS SMAS Bawari Pontianak?"

Agar penelitian lebih fokus dan terarah dengan jelas, maka peulis merumuskan beberapa sub masalah dalam penelitian ini yaitu sebagai berikut:

1. Bagaimana lingkungan keluarga mendukung kegiatan belajar siswa kelas XI IIS Smas Bawari Pontianak? 
2. Bagaimana prestasi belajar siswa kelas XI IIS Smas Bawari Pontianak?

3. Apakah ada pengaruh lingkungan keluarga terhadap prestasi belajar siswa kelas XI IIS Smas Bawari Pontianak?

4. Seberapa besar pengaruh ligkungan keluarga terhadap prestasi belajar siswa kelas XI IIS Smas Bawari Pontianak?

Berdasarkan masalah yang dirumuskan tersebut, penelitian ini bertujuan sebagai berikut:

1. Mengetahui lingkungan keluarga siswa dalam mendukung kegiatan belajar siswa kelas XI IIS Smas Bawari Pontianak.

2. Mengetahui prestasi belajar siswa kelas XI IIS Smas Bawari Pontianak.

3. Mengetahui pengaruh lingkungan keluarga terhadap prestasi belajar siswa kelas XI IIS Smas Bawari Pontianak

4. Mengetahui besarnya pengaruh lingkungan keluarga terhadap prestasi belajar siswa kelas XI IIS Smas Bawari Pontianak

\section{METODE PENELITIAN}

Dalam penelitian ini akan menggunakan pendekatan penelitian kuantitatif. Penelitian kuantitatif dikaitkan dengan data numerik dan ketepatan. Menurut Sugiyono (2014:3) "Metode penelitian diartikan sebagai cara ilmiah untuk

Berdasarkan bentuk penelitian tersebut, maka bentuk penelitian yang ditetapkan adalah studi hubungan (Interrelationship Stidies) atau yang biasa disebut korelasi. Menurut Sanjaya (2015:37) "Penelitian Korelasi adalah penelitian yang dilakukan untuk menemukan ada atau tidaknya hubungan antar dua atau lebih variabel yang diteliti", sejalan dengan pendapat Margono (2009:9) "Penelitian korelasi bertujuan melihat hunungan antara dua gejala atau lebih". Studi mendapatkan data dengan tujuan dan kegunaan tertntu". Sedangkan menurut Silaen (2018:18) "Penelitian yang menghasilkan data berupa angka-angka dan umumnya dianalisasi dengan menggunakan statistik deskriptif.

Dari beberapa pengertian tersebut dapat disimpulkan bahwa metode penelitian adalah cara yang digunakan oleh peneliti untuk memecahkan permasalahan yang diteliti. Maka metode yang akan digunakan dalam penelitian ini adalah metode deskriptif.

Metode deskriptif dapat diartikan sebagai prosedur pemecahan masalah yang sedang diselidik dengan menggambarkan/melukiskan keadaan subjek/subjek peneliti (seseorang, lembaga, masyarakat dan lain-lain) pada saat sekarang berdasarkan fakta-fakta yang tampak atau sebagaimana adanya.

Bentuk penelitian ini adalah penelitian deskriptif, menurut Nawawi (2012:68-81) bahwa pada dasarnya penelitian deskriptif diberikan menjadi 3 bentuk yaitu :

1. Survei (Survey Studies)

2. Studi Hubungan (Interrelationship Stidies)

3. Studi Perkembangan (Developmental Studies)

korelasional berupaya mencari hubungan antara variabel-variabel yang diteliti.

Populasi dalam penelitian ini adalah siswa kelas XI IIS SMA Bawari Pontianak berjumlah 102 siswa. Berikut jumlah data siswa kelas XI SMAS Bawari Pontianak.

Berdasarkan perhitungan diatas maka sampel dalam penelitian ini untuk setiap kelas adalah sebagai berikut :

Tabel 1 Perhitungan Sampel Siswa SMA Bawawi Pontianak

\begin{tabular}{clcc}
\hline Kelas & Jumlah & Perhitungan Sampel & Jumlah Sampel \\
\hline XI IIS 1 & 34 Siswa & $34 / 102$ x 50 & 17 Siswa \\
\hline XI IIS 2 & 33 Siswa & $33 / 102 \times 50$ & 16 Siswa \\
\hline XI IIS 3 & 35 Siswa & $35 / 102$ x 50 & 17 Siswa \\
\hline Jumlah & 102 Siswa & 50 Siswa \\
\hline $\begin{array}{l}\text { Sampel sebanyak 50 siswa yang terdiri dari 3 } \\
\text { kelas dipilih dengan cara simple random sample } \\
\text { (simple random sederhana) }\end{array}$ & $\begin{array}{c}\text { Tekhnik pengumpulan data yang } \\
\text { dilakukan yaitu : } \\
\text { 1. Tekhnik komunikasi langsung adalah } \\
\text { "Cara mengumpulkan data yang }\end{array}$
\end{tabular}


mengharuskan seorang peneliti mengadakan kontak langsung secara lisan atau tatap muka (face toface) dengan sumber data, baik dalam situasi yang sebenarnya maupun

situasi dibuat untuk keperluan tersebut".

2. Teknik komunikasi tidak langsung adalah "Cara mengumpulkan data yang dilakukan dengan mengadakan hubungan tidak langsung atau perantara alat, baik berupa alat sudah tersedia maupun alat khusus yang dibuat untuk keperluan itu".

3. Teknik studi dokumenter adalah "Cara mengumpulkan data yang dilakukan dengan katagori dan klarifikasi bahanbahan tertulis yang berhubungan dengan penelitian, baik dari sumber dokum maupun buku-buku, majalah dan lainlain".

Alat pengumpulan data yang di ambil dalam penelitian ini yaitu:

1. Angket (kuesioner) yaitu pengumpulan data yang dilakukan dengan cara memberi seperangkat pernyataan atau pertanyaan tertulis kepada responden untuk dijawabnya.

2. Catatan-catatan yaiutu berupa pengumpulan catatan arsip berupa prestasi belajar siswa

Data dalam penelitian ini berupa angka dan terdiri dari satu variabel bebas dan satu variabel terikat sehingga penelitian menggunakan analisis regresi linear sederhana. Menurut Sugiyono (2016:261), "Regresi sederhana lebih mendasar pada hubungan fungsional ataupun kausal satu variabel independen dan satu variabel dependen". Hal ini bertujuan untuk mengetahui apakah naik turunnya nilai variabel terikat dipengaruhi jika nilai variabel bebas dinaikan atau diturunkan sehingga peneliti dapat mengetahui apakah ada pengaruh atau tidak antara kedua variabel tersebut. Hal ini di dukung oleh penjelasan Sugiyono (2016:215), "Kegunaan analisis adalah untuk melakukan preseksi, bagaimana perubahan nilai variabel dependen apabila nilai variabel independen dinaikan atau diturunkan nilainya". Untuk mengetahui ada tidaknya pengaruh lingkungan keluarga (variabe bebas) terhadap prestasi belajar (variabel terikat) dalam penenlitian ini menggunakan program statistik SPSS 18.00 dengan rumus regresi sederhana sehingga setelah dilakukannya perhitungan melalui analisis regresi sederhana akan diperoleh nilai regresi yang menggambarkan seberapa besar pengaruh variabel bebas terhadap variabel terikat. Secara umum, persamaan regresi sederhana (dengan satu prediktor)

Menurut Arikunto (2012:211) "Validitas adalah suatu ukuran yang menunjukan tingkattingkat kevalidan atau kesahihan sesuatu instrumen". Dalam pengujian validitas ini pada tahap awal peneliti melakukan knsultasi kepada dosen pembimbing,kemudian setelah mendapatkan persetujuan penelitian melakukan uji coba instrument dengan jumlah sampel 20 orang kepada siswa kelas XI IIS SMAS Bawawi Pontianak secara acak. Selanjutnya data dikumpulkan dan diolah dengan menggunkan krelasi product moment. Perhitungan menggunakan korelasi Pearson Product Moment tersbut dilakukan dengan bantuan program SPSS 18:00 guna mendapatkan validitas. Rumus validitas untuk melihat tabel distribusi $\mathrm{r}$ berdasarkan $\mathrm{DF}$ sebesar $\mathrm{N}-2=20-2=18$ maka nilai $\mathrm{r}$ tabel sebesar 0,378 .

Uji Reabilitas berkenan dengan derajad kostitensi dan stabititas data atau lebih penelitian dalam objek yang sama menghasilkan data yang samaatau sekelompok data bila dipecah menjadi dua menunjukan data yang tidak berbeda. Maka dari itu penulis merasa perlu mengadakan uji reabiloitas agar instrument yang digunakan itu benar-benar menjadi alat ukur yang sesuai atau dipercaya

Uji normalitas data dilakukan sebelum data diolah berdasarkan model-model penelitian. Uji normalitas ini bertujuan untuk mengetahui distribusi data dalam variabel yang akan digunakan dalam penelitian.

Uji Hipotesis Nol (H0) Tidak terdapat pengaruh lingkungan keluarga terhadap prestasi belajar siswa kelas XI IIS di Smas Bawari Pontianak tahun ajaran 2019/2020. 
Secara mataematika dirumuskan bahwa $\mathrm{H} 0=0$ Hipotesis Alternatif (Ha) Terdapat pengaruh lingkungan keluarga terhadap prestasi belajar siswa kelas XI IIS di Smas Bawari Pontianak tahun ajaran 2019/2020, Secara matematikanya dirumuskan bahawa $\mathrm{Ha} \neq \mathrm{O}$.

\section{HASIL PENELITIAN DAN PEMBAHASAN}

Pada penelitian ini bertujuan untuk mengetahui pengaruh lingkungan keluarga terhadap prestasi belajar siswa kelas XI IIS SMAS Bawari Pontianak. Sampel data yang digunakan sebanyak 50 siswa yang berasal dari tiga kelas, dimana setiap kelas diwakili oleh 17 siswa dari kelas XI IIS 1, 16 siswa dari kelas XI IIS 2 dan 17 siswa dari kelas XI IIS 3. Siswa yang dipilih dengan cara simple random sample. Untuk mendeskripsikan data dari variabel bebas yaitu Faktor Lingkungan Keluarga (X) dan variabel terikat yaitu prestasi belajar (Y)

\section{Variabel Prestasi Belajar (Y)}

Data mengenai variabel prestasi belajar ekonomi dalam penelitian ini diperoleh dari rata-rata raport siswa kelas XI IIS SMAS Bawari Pontianak 2019/2020 sebanyak 50 peserta didik. Berdasarkan perhitungan statistik diperoleh hasil skor tertinggi yang diperoleh sisiwa adalah 75 dan skor terendah adalah 46, jumlah nilai seluruh siswa adalah 3203,60 dan rata-rata prestasi belajar kelas XI IIS yaitu 64,07.

Variabel Lingkungan Keluarga (X) Indikator lingkungan keluarga yang digunakan dalam penelitian ini ada 5 antara lain cara orang tua mendidik, relasi antar anggota keluarga, suasana rumah, keadaan ekonomi keluarga dan latar belakang kebudayaan. Dalam penelitian ini menggunakan angket dengan 21 butir soal.

Uji Instrumen Kuisioner Validitas berasal dari kata validity yang mempunyai arti sejauhmana ketepatan dan kecermatan suatu alat ukur dalam melakukan fungsi ukurnya. Valid tidaknya suatu alat ukur tergantung pada mampu tidaknya alat ukur tersebut mencapai tujuan pengukuran yang dikehendaki dengan tepat. Suatu kuesioner dikatakan valid jika pertanyaan pada suatu kuesioner mampu untuk mengungkapkan sesuatu yang akan diukur oleh kuesioner tersebut.

Hipotesis Uji H0 : $\rho$ terkoreksi $\leq 0$ (skor variabel berkorelasi positif dengan skor faktor)
H1 : $\rho$ terkoreksi $>0$ (skor variabel tidak berkorelasi positif dengan skor faktor) Tingkat Signifikansi $\alpha=0,05$ Daerah Kritik H0 ditolak jika r_hasilpositif serta r_hasillebih besar dari r_tabel. Untuk penelitian ini, nilai df dapat dihitung sebagai berikut $\mathrm{df}=\mathrm{n}-2$ atau $50-2=$ 48, dengan tingkat signifikansi sebesar 0,05 maka didapat $r$ tabel sebesar 0,2353 (one tail).

Uji reliabilitas digunakan untuk mengukur konsistensi konstruk/variabel penelitian. Suatu variabel dikatakan reliable (handal) jika jawaban responden terhadap pertanyaan konsisten atau stabil dari waktu ke waktu. Tingkat reliabilitas suatu konstruk / variabel penelitian dapat dilihat dari hasil statistik Cronbach Alpha $(\alpha)$.

Uji asumsi klasik adalah uji untuk mengetahui apakah model memenuhi asumsi atau tidak. Ada pun uji asumsi klasik yang akan diuji yaitu uji normalitas, multikolinearitas, dan non heteroskedastisitas.

Analisis Regresi Linear Sederhana

Estimasi parameter dengan metode kuadrat terkecil untuk prestasi belajar siswa (Y) dan lingkungan keluarga (X) dilakukan dengan software SPSS

Uji Koefisien Determinasi Koefisien determinasi menjelaskan variasi pengaruh variabel independen terhadap variabel dependen atau dapat pula dikatakan sebagai proporsi pengaruh seluruh variabel independen terhadap variabel dependen. Nilai koefisien determinasi dapat diukur oleh nilai R-Square atau Adjusted R-Square (Adjusted)

\section{PEMBAHASAN}

\section{Lingkungan Keluarga Siswa Kelas XI IIS SMAS Bawari Pontianak}

Hasil penelitian berdasarkan lingkungan keluarga siswa kelas XII IIS SMAS, kepada siswa diperoleh bahwa didalam lingkungan keluarga yang banyak terjadi pada siswa di SMAS Bawari Pontianak kelas XII IIS adalah siswa jarang berselisih paham dengan orang tua, hal ini dibuktikan sebanyak 33 siswa menjawab tidak pernah berselisih paham dengan orang tuanya. Penelitian ini sejalan dengan menurut pendapat Gunarsa (2009: 5) "Lingkungan keluarga ialah lingkungan pertama yang mula-mula memberikan pengaruh yang mendalam bagi anak dari 
anggota-anggota keluarganya dan suadaranya". Berdasarkan angket yang diberikan peneliti kepada siswa diperoleh bahwa didalam lingkungan keluarga yang banyak terjadi pada siswa di SMAS Bawari Pontianak kelas XI IIS adalah siswa jarang berselisih paham dengan orang tua, hal ini dibuktikan sebanyak 33 siswa menjawab tidak pernah berselisih paham dengan orang tuanya.

Orang tua selalu memprioritaskan pengeluaran untuk pendidikan, hal ini ditunjukkan oleh hasil angket yaitu sebanyak 31 siswa menjawab orang tua selalu memprioritaskan pengeluaran untuk pendidikan. Orang tua selalu memberikan uang kepada siswa apabila siswa meminta uang untuk keperluan sekolah, hal ini ditunjukkan oleh hasil angket yaitu sebanyak 33 siswa menjawab selalu diberikan orang tua uang ketika meminta uang untuk keperluan sekolah. Lingkungan keluarga siswa kelas XI IIS SMAS Bawari Pontianak menurut peneliti memiliki lingkungan keluarga yang sangat baik, hal ini berdasarkan indikator lingkungan keluarga yaitu indikator cara orang tua mendidik 83,66 \% dikategorikan sangat baik, indikator relasi anggota keluarga 82,87 \% dikategorikan sangat baik, indikator suasana rumah 82,7 \% dikategorikan sangat baik dan indikator latar belakang budaya 84,5 \% dikategorikan sangat baik.

\section{Prestasi Belajar Siswa kelas XI IIS SMAS Bawari Pontianak \\ Penilaian pendidikan \\ tentang}

perkembangan dan kemajuan peserta didik yang berkenaan dengan penguasaan bahan pelajaran yang disajikan kepada peserta didik serta nilainilai yang terdapat pada kurikulum. Menurut Winkel (2015:81) “ Prestasi belajar ialah bukti keberhasilan yang telah dicapai oleh seseorang dengan hasil yang maksimum setelah melakukan usaha-usaha belajar". Prestasi belajar siswa kelas XI IIS SMAS Bawari Pontianak diperoleh berdasarkan nilai rata-rata raport siswa pada semester sebelumnya.

Diperoleh bahwa nilai terendah prestasi belajar siswa adalah 46 dan yang tertinggi adalah 75. Jumlah nilai seluruh siswa adalah 3203,60 dengan rata-rata prestasi belajar adalah 64,07 . Berdasarkan tiga kelas yang dijadikan sampel penelitian, diperoleh jumlah nilai kelas XI IIS 1 adalah 1122,60 dengan rata-rata prestasi belajar adalah 66,04. Jumlah nilai kelas XI IIS 2 adalah 1015,00 dengan rata-rata prestasi belajar adalah
63,44. Jumlah nilai kelas XI IIS 3 adalah 1065,00 dengan rata-rata prestasi belajar adalah 62,69. Sehingga dapat disimpulkan bahwa kelas dengan prestasi belajar tertinggi yaitu kelas XI IIS 1 diikuti dengan kelas XI IIS 2 dan yang terakhir yaitu kelas XI IIS 3 .

\section{Pengaruh Lingkungan Keluarga Dengan Prestasi Belajar Siswa Kelas XI IIS SMAS Bawari Pontianak \\ Berdasarkan hasil analisis dengan} menggunakan bantuan computer, Berdasarkan output SPSS uji t diperoleh nilai _ $\_$hitung $_{2}=24,542$ $>\mathrm{t}_{\text {tabel }}=2,010$ Sehingga dapat disimpulkan bahwa terdapat pengaruh lingkungan keluarga mempengaruhi prestasi belajar siswa kelas XI IIS SMAS Bawari pontianak. Berdasarkan output SPSS uji $f$ diperoleh nilai $\mathrm{F}_{\text {hitung }}=959,579>\mathrm{F}_{\text {tabel }}=4,04$. Dapat disimpulkan bahwa terdapat pengaruh lingkungan keluarga mempengaruhi prestasi belajar siswa kelas XI IIS SMAS Bawari pontianak.

\section{Seberapa Besar Lingkungan Keluarga Mempengaruhi Prestasi Belajar Siswa Kelas XI IIS SMAS Bawari Pontianak}

Berdasarkan analisis regresi linear sederhana diperoleh model persamaan regresi pengaruh lingkungan keluarga terhadap prestasi belajar siswa kelas XI IIS SMAS Bawari Pontianak yaitu. $\mathrm{Y}=31,13+0,53 \mathrm{X}$

Berdasarkan model yang diperoleh dapat disimpulkan bahwa lingkungan keluarga berpengaruh positif terhadap prestasi belajar siswa kelas XI IIS SMAS Bawari Pontianak. Semakin baik kondisi lingkungan keluarga maka akan semakin bagus prestasi belajar siswa kelas XI IIS di SMAS Bawari Pontianak dan sebaliknya, semakin buruk kondisi lingkungan keluarga maka akan semakin menurun prestasi belajar siswa kelas XI IIS di SMAS Bawari Pontianak. Berdasarkan model tersebut, ketika lingkungan keluarga bernilai nol, maka prestasi belajar siswa kelas XI IIS di SMAS Bawari Pontianak akan bernilai 31,13. Ketika kondisi lingkungan keluarga membaik sebesar 1 persen, maka prestasi belajar siswa kelas XI IIS di SMAS Bawari Pontianak akan naik sebesar 0,53 persen dan sebaliknya ketika kondisi lingkungan keluarga memburuk sebesar 1 persen, maka prestasi belajar siswa kelas XI IIS di SMAS Bawari Pontianak akan 
menurun sebesar 0,53 persen. Diperoleh nilai adjusted $\mathrm{R}$ square dari model persamaan regresi yaitu sebesar 0,951 , yang artinya lingkungan keluarga mempengaruhi prestasi belajar siswa sebesar $95,1 \%$ dan sisanya $4,9 \%$ dijelaskan oleh variabel lain yang belum terdapat didalam model. Serta nilai standard error yang diperoleh pada model tersebut yaitu sebesar 1,37920.

\section{KESIMPULAN DAN SARAN}

\section{Kesimpulan}

Berdasarkan analisis yang telah dilakukan pada BAB IV diperoleh beberapa kesimpulan antara lain: (1)Lingkungan keluarga siswa kelas XI IIS SMAS Bawari Pontianak memiliki skor 3514 dapat dipresentasikan 83,66 \% dikategorikan sangat baik. (2) Berdasarkan tiga kelas yang dijadikan sampel penelitian, diperoleh rata-rata prestasi belajar kelas XI IIS 1 adalah 64,07. (3) Pengaruh lingkungan keluarga dengan prestasi belajar siswa kelas XI ISS SMAS Bawawi Pontianak. Berdasarkan uji hipotesis diperoleh nilai $t_{\_}$hitung $=(30,977)$ lebih besar dari $\mathrm{t}_{-}$tabel$=2,010$. Maka dapat disimpulkan terdapat pengaruh lingkungan keluarga terhadap prestasi belajar siswa kelas XI IIS SMAS Bawari pontianak. (4)Seberapa besar lingkungan keluarga mempengaruhi prestasi belajar siswa kelas XI . Lingkungan keluarga mempengaruhi prestasi belajar siswa sebesar $95,1 \%$ dan sisanya $4,9 \%$ dijelaskan oleh variabel lain yang belum terdapat

\section{Saran}

Berdasarkan analisis yang telah dilakukan yaitu pengaruh lingkungan keluarga terhadap prestasi belajar siswa kelas XI IIS di SMAS Bawari Pontianak, diperoleh beberapa saran antara lain: (1) Bagi orang tua/wali siswa Diharapkan kedepannya bagi orang tua/wali siswa dapat lebih memberikan perhatian lebih kepada siswa guna terciptanya prestasi belajar siswa yang lebih baik lagi. (2) Bagi siswa

Bagi siswa kedepannya bisa lebih giat lagi dalam belajar agar bisa memperoleh prestasi belajar yang lebih maksimal lagi. Siswa diharapkan kedepannya apabila ditemukan permasalahan didalam lingkungan keluarga, dapat menceritakan masalah tersebut kepada guru atau wali kelas, agar diperoleh solusi dari permasalahan tersebut
(3).Bagi guru Guru diharapkan bisa memberikan motivasi serta bimbingan kepada orang tua/wali siswa dan siswa kelas XI IIS di SMAS Bawari Pontianak agar bisa menciptakan kondisi lingkungan keluarga yang baik agar diperoleh prestasi belajar siswa yang maksimal. (4) Penelitian yang akan datang. Diharapkan penelitian yang akan datang, sampel yang digunakan lebih banyak sehingga hasil dari analisis dari penelitian yang didapatkanakan lebih akurat. Melakukan penelitian dengan aspek yang sama dengan menambahkan variabel yang menyangkut aspek tersebut untuk lebih mengetahuivariabelvariabel lain yang mempengaruhi prestasi belajar siswa.ss

\section{DAFTAR RUJUKAN}

Arikunto, S. (2013). Prosedur Penelitian, Jakarta: PT.Rineka Cipta

Astuti, 1. (2016). Quality Time With Kids:Cerdas Kilat Tingkatan Presentasi Belajar \& Semakin Dekat Dengan Anak. Yogyakarta: andi

Nuraini, A. (2017). Format Penulisan Karya Ilmiah Edisi Kedelapan (revisi). Pontianak: FKIP UNTAN.

Duvall \& Logan, (1986). Marriage and Family Development. New York: Harper dan Row Publisher.

Hasbullah, (2011). Dasar-Dasar Ilmu Pendidikan. Jakarta. Rajawali Pers.

Kadir, A. (2012). Dasar-Dasar Pendidikan, Jakarta: Kencana Prenada Media Group.

Kidder, (1981). Research Methods In Social Relation. New York: Rinehart danWisnton

Dewantara, K.H. (2014). Lingkungan Pendidikan Jakarta: Cipta Karya.

Sanjaya, W. (2015). Penelitian Pendidikan. Jakarta: Predana Media Group

Saifudin, A. (1996). Introduction To Integration Psychology. Jogyakarta: Pustaka

Silaen, (2018). Metode penelitian sosial. Bogor: Penerbit In Media

Slameto, (2015). Belajar dan Faktor-Faktor yang Mempengaruhinya. (Cetakan Ke 6). Jakarta: PT. Rineka Cipta. 
Sugiyono, (2018). Metode Penelitian Kombinasi

(Mixed Methods). Bandung: Alfabeta.

Sumber web :

http//www.sarjanaku.com/2013/20

14/pengertian keluarga-

fungsi-faktor.html

http://ainamulyaa.blogspot.com/2

016/01/prestasi-belajar-

siswa-pengertian dan $\mathrm{html}$

Syah, M. (2008). Psikologi Pendidikan

Dengan Pendekatan Baru

Bandung: PT Remaja Rosda

Tu u, (2014). Peranan Displin Pada Perilaku Dan

Prestasi Siswa. Jakarta:

Grasindo

Winkel, WS. (1987). Guidance and Counseling

In Educational

Institutions jakrta:

Gramedia. 